\title{
Analyses of sexual reproductive traits in Dactylorhiza majalis: a case study from East Germany
}

\author{
Roland Schubert $^{1} \cdot$ Markus Brugger $^{1} \cdot$ Samantha Kühnel ${ }^{1} \cdot$ Heike Hohlfeld $^{1} \cdot$ Christa Maria Heidger $^{1}$
}

Received: 16 April 2019 / Accepted: 10 January 2020 / Published online: 28 January 2020

(C) The Author(s) 2020

\begin{abstract}
The orchid species Dactylorhiza majalis is endangered by continuing habitat destruction and fragmentation. This requires more detailed information with respect to its sexual reproduction, which is especially relevant for Germany, where from $10 \%$ to $30 \%$ of the world-wide remaining populations grow. In the present study, we determined both the numbers of growing and flowering individuals per stand with regard to D. majalis at 12 localities of Upper Lusatia, Saxony, Germany, during the season 2014. For up to 25 plants per stand, sexual reproduction was assessed by checking over the numbers of blossoms and fruits per inflorescence and by calculating percentages of seed fertilities from embryo-viability stains. Applying pair-wise statistical analyses, we found correlations between two of the above-mentioned traits as well as among the above-cited population-specific reproduction parameters and four out of six Ellenberg's indicator values, which have been calculated to characterize local site conditions. We furthermore recorded both very poor and enhanced seed fertilities, clustering into two groups which were associated with the Ellenberg's indicator value thermal continentality. Lower seed fertilities were generally detected in the northern lowlands, whereas D. majalis is probably able to compensate the unpleasant environments of the southern highlands by bearing more fertile seeds. Conducting genetic inventories with three nuclear microsatellites, the sampled seed-producing mother plants of both fertility groups differed by the opposite frequency distribution of two prominent genotypes DD and EE at locus ms14. These findings indicate a genetic selection due to adaptation to climatical stresses. Based on the additionally detected aberrant megasporogenesis, we propose that mother plants of homozygous genotype EE and their germ-cells are less affected by both aneuploidy and large deletions on the remaining chromosomes, and we assume that a linkage disequilibrium exists between such advantageous karyotypes and the studied microsatellite locus. Regarding the challenges of global warming, repeated inventories are finally recommended at all 12 stands in order to validate the long-term indicative properties of the discovered findings.
\end{abstract}

Keywords Chromosomes · Climatic adaptation · Dactylorhiza majalis $\cdot$ Microsatellite markers $\cdot$ Sexual reproduction

\section{Introduction}

The perennial broad-leaved marsh orchid Dactylorhiza majalis (Reichenbach) P. F. Hunt and Summerhayes (1965) occurs in different types of Eurasian wetlands (Delforge 2006). Because such wetlands, e.g., coastal and forested wetlands, marshes, fens, bogs, peatlands, and floodplains, have been gradually removed from the landscape for human uses,

Roland Schubert

r.schubert@hszg.de

1 Faculty of Natural and Environmental Sciences, University of Applied Sciences Zittau/Görlitz, Theodor-Körner-Allee 16, 02763 Zittau, Germany
D. majalis has become a rare species. Protection of natural refuges from drainage systems and intensive agriculture as well as the restoration of lost wetlands are remarkable efforts to save this taxon at least on a local scale. D. majalis suffers, however, from the conditions of an extensive agricultural management, when competitive flora is not regularly removed at the end of the season (Wotavová et al. 2004).

Due to ongoing habitat destruction and fragmentation (Riecken et al. 2006; Liu et al. 2016), D. majalis is present on many German regional Red Lists of endangered species as has been recently reported for the Upper Lusatia region, situated in East Saxony, and Thuringia (Bräutigam and Otto 2012; Rode and Schadwinkel 2014). To prevent this rare species from further decline, more efficient conservation actions are urgently needed, especially when considering the fact that from $10 \%$ to $30 \%$ of the world-wide D. majalis populations 
grow in Germany (Ludwig et al. 2007). Despite this importance, relatively little attention has been paid, however, to evaluate the current sexual fitness of German D. majalis stands by carrying-out an exact identification of flowering access and fruit production as proposed by Heinrich (2013).

Regarding the fact that $D$. majalis increasingly occurs in small relict populations, it could be threatened by a reduction of genetic variability in response to random drift processes and inbreeding. For statistics identifying this disadvantageous situation in plants, connected to homozygosity excesses in terms of Hardy-Weinberg equilibrium (HWE), a failure to adapt to shifting environments, and insufficient fertility, see Yeh (2000). The floral composition of Upper Lusatia is furthermore expected to be affected by forecast increasing temperatures in spring and dry summers due to global climate change (Flemming 2005; Kreienkamp et al. 2011). In order to get a better understanding in how far the sexual reproduction of D. majalis is influenced by the above-mentioned variety of genetic and environmental stresses, local population surveys have a high priority. The knowledge, gained from such studies, may provide new scientific information to implement site-specific conservation strategies in the future.

D. majalis represents a naturally occurring allotetraploid hybrid between diploid Dactylorhiza incarnata (Linné) Soó (1960) and diploid Dactylorhiza fuchsii (Druce) Soó (1960) that unifies 80 tiny roundish chromosomes within a single cellular nucleus. This complex genome combination, corresponding to marked morphological traits, has been originally confirmed by cytological investigations (pointed out by Heslop-Harrison 1953; Hunt and Summerhayes 1965) and was later on characterized using different types of genetic markers (Hedrén 1996; Devos et al. 2003; Devos et al. 2006; Paun et al. 2011; Balao et al. 2016). Allopolyploids are usually more vigorous in comparison to their parental species taking advantage from both gene-dosage and heterosis effects (Comai 2005). They can furthermore readily adapt to changing environments (Paun et al. 2010) and defend ecological niches in disturbed areas as documented by the fact that D. incarnata disappeared over time from Upper Lusatia, while D. majalis is still present (Bräutigam and Otto 2012). As has been reviewed by Comai (2005), allopolyploid hybrids are known to protect their unique gene pool by a strong reproductive isolation, which is indicated by numerous prezygotic barriers (e.g., floral isolation, highly specialized pollination vectors, or pollen-pistil incompatibility) and postzygotic barriers. The latter leads to a mosaic of differential fertility amongst outcrossing offspring, including inviable embryos and endosperm malfunctions, which is caused by altered chromosomal structures and numbers and/or incompatible gene functions with respect to nuclear genomes and organelle DNA variants (for reviewing basic principles of widespread hybridization events within the plant kingdom see Burke and Arnold 2001; Mallet 2005; Baack and Rieseberg 2007; Soltis and Soltis 2009).

In the present investigation, we examined the current sexual reproduction of 12 D. majalis stands in Upper Lusatia by a broad range of methods including environmental assessments, embryo-viability stains, chromosomal records, and genetic inventories of mother plants. Main aims of our study were i) to count the number of growing D. majalis individuals and to assess flowering, fruit-set, and embryo viability within stands; ii) to identify local site conditions and certain genotypes beneficial for sexual reproduction; iii) to find possible genetic loads and environmental factors of diminishing concern to the production of offspring.

\section{Material and methods}

\section{Study area and fitness assessment of $D$. majalis}

Twelve orchid stands in the Upper Lusatia region were investigated during the growing season of the year 2014. Note that five stands represent the northern lowland and the remaining seven climb from the southern lowland to the mountains (Fig. 1). The absolute number of all growing $D$. majalis plants and their flowering access (absolute number of flowering individuals) were counted one-by-one in case of small populations. Extent and flowering intensity of large populations were estimated. Absolute numbers of blossoms and seed-producing fruits were determined per inflorescence and averaged over the total number of investigated sexually reproducing mother plants per stand (up to 25 , collecting more was not allowed by the local environmental protection authority). Sampling of clonal groups of mother plants, derived from the same individual by asexual reproduction, was avoided by selecting unnested individuals even within small test populations. Leaves and seeds of the examined mother plants were further analyzed as described below (Tables 1 and 2).

\section{Chromosomal smears}

When D. majalis appeared in the field, roughly about a month before flowering, megasporocytes were fixed in a fluid of absolute methyl alcohol and glacial acetic acid (ratio of 3:1 by volume) for at least $1 \mathrm{~h}$. They were then macerated and stained by acetocarmine at $95^{\circ} \mathrm{C}$ for $10 \mathrm{~min}$. A stock solution was previously prepared by dissolving $1 \mathrm{~g}$ carmine in $100 \mathrm{ml}$ of boiling $45 \%(\mathrm{v} / \mathrm{v})$ acetic acid, which was then filtered and stored at room temperature until use (Sass 1958). Treated megasporocytes were finally transferred in a fresh drop of acetocarmine and smeared by gently pressing a cover glass against the slide. The obtained chromosomal plates were 
Fig. 1 Geographic map of Upper Lusatia, showing the local positions of 12 sampled D. majalis populations as indicated by dot symbols: 1 , Zedlig (160 $\mathrm{m}$ a.s.1.); 2, Petershain (163 m a.s.1.); 3 , Zeche-Nord (166 m a.s.1.); 4, Zeche-Süd (163 m a.s.1.); 5, Horka (181 m a.s.1.); 6, Schlegel (324 $\mathrm{m}$ a.s.1.); 7, Eichgraben (283 m a.s.1.); 8, Hartau (282 $\mathrm{m}$ a.s.1.); 9, Jonsdorf (376 $\mathrm{m}$ a.s.1.); 10, Waltersdorf (551 m a.s.1.); 11, Leutersdorf (390 m a.s.l); 12, Seifhennersdorf (411 $\mathrm{m}$ a.s.l.). The borders across Germany, Poland, and Czech Republic are drawn. The arrow marks the north point $(\mathrm{N})$ of the compass. (a.s.l. = above sea level)

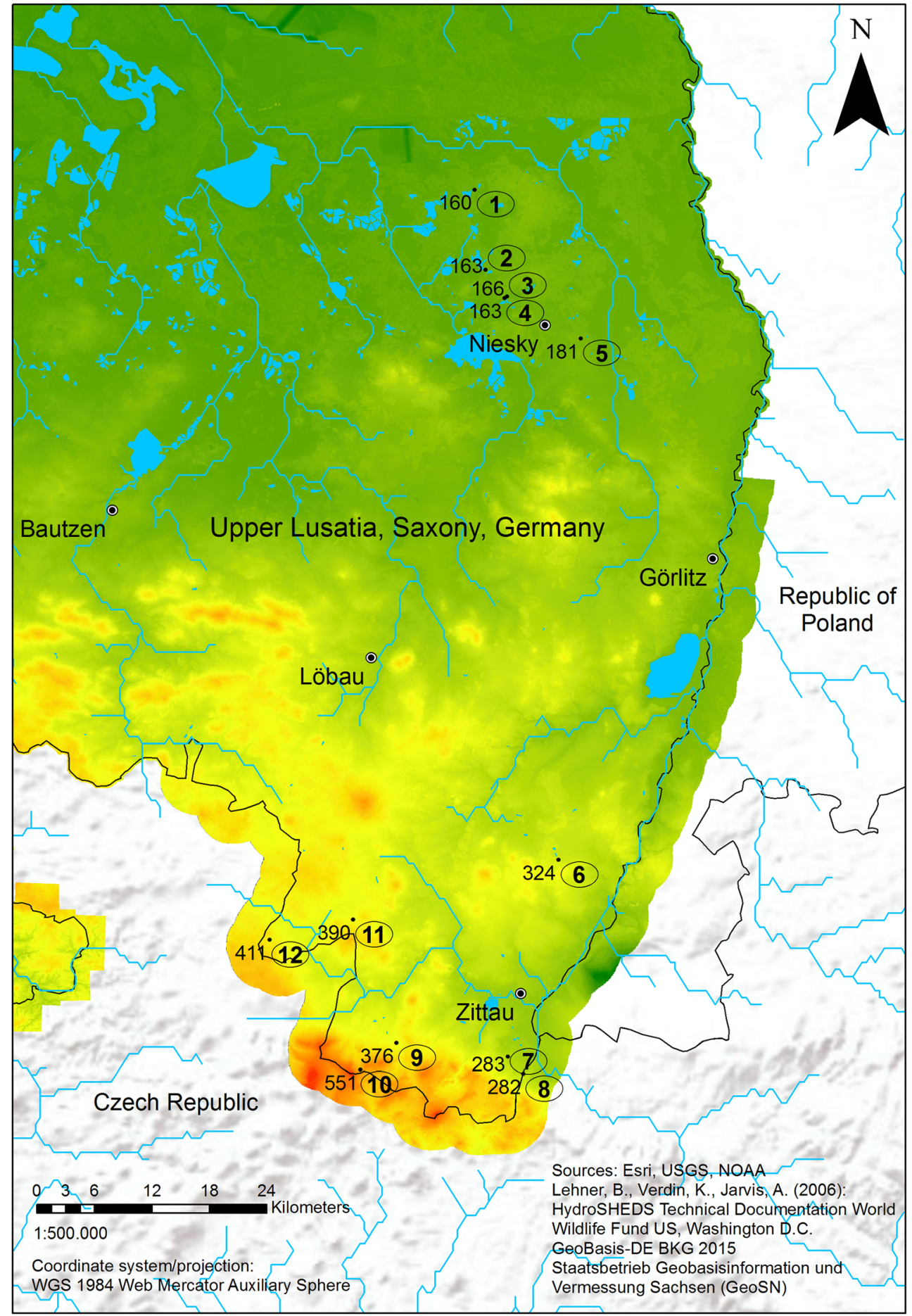

subjected for microscopic investigation and photographical documentation after removing excess stain by a paper tissue.

\section{Genetic inventories}

We selected three target-specific PCR primer pairs from the literature (Nordström and Hedrén 2007), which are known to amplify nuclear-encoded microsatellites (ms) either in diploid
D. incarnata (ms3) or diploid D. fuchsii (ms13 and ms14), respectively. Because these microsatellites are unique markers for only one parental genome when below-testing the allotetraploid hybrid $D$. majalis, easily interpretable codominant PCR product patterns were found which refer to a single Mendelian locus. This allowed the distinction of heterozygous genotypes (i.e., two different gel electrophoresis bands) from homozygous genotypes (i.e., only one band). 
Table 1 Summary statistics listing growth and distinct sexual reproduction parameters for $12 \mathrm{D}$. majalis populations which have been inventoried in the Upper Lusatia region in 2014

\begin{tabular}{llllll}
\hline $\begin{array}{l}\text { Population } \\
\text { no. }\end{array}$ & $\begin{array}{l}\text { Absolute number of } \\
\text { growing individuals }\end{array}$ & $\begin{array}{l}\text { Absolute number of } \mathrm{f} \\
\text { lowering individuals }{ }^{\mathrm{a}}\end{array}$ & $\begin{array}{l}\text { Average number of } \\
\text { blossoms per inflorescence }\end{array}$ & $\begin{array}{l}\text { Relative fruit-building } \\
\text { rate }^{\mathrm{c}}\end{array}$ & $\begin{array}{l}\text { Relative seed-fertility } \\
\text { rate }^{\mathrm{d}}\end{array}$ \\
\hline 1 & 538 & $88(0.164)$ & $13 \pm 4(25)$ & $0.537 \pm 0.245(11)$ & $0.1345 \pm 0.1121(4400)$ \\
2 & 45 & $30(0.667)$ & $15 \pm 5(25)$ & $0.615 \pm 0.303(10)$ & $0.0750 \pm 0.0834(4000)$ \\
3 & 8000 & $3000(0.375)$ & $24 \pm 6(25)$ & $0.442 \pm 0.151(25)$ & $0.0424 \pm 0.0366(10000)$ \\
4 & 325 & $275(0.846)$ & $20 \pm 7(25)$ & $0.478 \pm 0.204(22)$ & $0.0641 \pm 0.0575(8800)$ \\
5 & 1350 & $900(0.667)$ & $19 \pm 7(25)$ & $0.548 \pm 0.210(23)$ & $0.0904 \pm 0.0903(9200)$ \\
6 & 825 & $275(0.333)$ & $15 \pm 5(25)$ & $0.576 \pm 0.241(17)$ & $0.1641 \pm 0.1204(6800)$ \\
7 & 55 & $35(0.636)$ & $16 \pm 6(25)$ & $0.439 \pm 0.355(6)$ & $0.0883 \pm 0.0492(2400)$ \\
8 & 44 & $19(0.432)$ & $16 \pm 4(25)$ & $0.693 \pm 0.155(16)$ & $0.1288 \pm 0.0831(6400)$ \\
9 & 1200 & $800(0.667)$ & $32 \pm 14(25)$ & $0.317 \pm 0.155(23)$ & $0.1478 \pm 0.1040(9200)$ \\
10 & 35 & $25(0.714)$ & $16 \pm 5(25)$ & $0.565 \pm 0.266(18)$ & $0.1500 \pm 0.1228(7200)$ \\
11 & 410 & $335(0.817)$ & $22 \pm 7(21)$ & $0.311 \pm 0.232(19)$ & $0.1568 \pm 0.1506(7600)$ \\
12 & 1225 & $1100(0.898)$ & $27 \pm 8(25)$ & $0.493 \pm 0.165(24)$ & $0.0733 \pm 0.0515(9600)$ \\
\hline
\end{tabular}

${ }^{a}$ Relative data with reference to the sum of growing plants are given in brackets; ${ }^{b}$ Arithmetic mean \pm standard deviation (rounded to integers), with the numbers of inspected plants printed in parentheses; ${ }^{\mathrm{c}}$ Arithmetic mean \pm standard deviation, with the numbers of assessed plants printed in parentheses;

${ }^{\mathrm{d}}$ Arithmetic mean \pm standard deviation, with the numbers of tested seeds given in brackets

Individual leaves, harvested per stand from the abovementioned mother plants and dried in silica gels at $6^{\circ} \mathrm{C}$, were further treated for DNA extraction (Doyle and Doyle 1990) employing the NucleoSpin Plant II Kit (Macherey-Nagel, Germany). A total of 15 ng of genomic DNA was amplified in a final reaction volume of $25 \mu \mathrm{l}$ per plant, containing $0.26 \mu \mathrm{M}$ forward primer $\left(5^{\prime}\right.$ end-labelled with BMN-5 or BMN-6 for fluorescent detection by multiplex analysis), $0.26 \mu \mathrm{M}$ reverse primer (not labelled), $1.6 \mathrm{mM} \mathrm{MgCl}, 125 \mu M$ of each dNTP, $2.5 \mu \mathrm{l} 10 \times$ PCR buffer, and 0.5 units Taq DNA polymerase (VWR). All primers were provided by biomers. net (Germany). Forty PCR cycles were conducted with the following parameters: denaturation at $94{ }^{\circ} \mathrm{C}$ for $60 \mathrm{~s}$; annealing at $54{ }^{\circ} \mathrm{C}$ for $60 \mathrm{~s}$ (ms3 and $\left.\mathrm{ms} 14\right)$ or alternatively at $55{ }^{\circ} \mathrm{C}$ for $60 \mathrm{~s}(\mathrm{~ms} 13)$; and extension at $72{ }^{\circ} \mathrm{C}$ for $90 \mathrm{~s}$.

PCR products were finally analyzed by use of the DNA separation capillary array $33-75 \mathrm{~B}$, running under control of a GeXP Genetic Analyzer (both instruments from Beckman Coulter, United States), to detect fluorescent bands by electrophoresis. The operating conditions were in accordance with the executable tools implemented by the manufacturer in the program software Frag-3. Exact genotypes for each studied microsatellite sample were identified during the electrophoretic run with the aid of the fluorescence detector and 22 internal molecular-weight standards, which have been previously labelled with WellRED ${ }^{\mathrm{TM}}$ fluorescent dye by GenomeLAB GeXP Consumables Chemistries (Beckman Coulter) before distributing.

\section{Embryo-viability stains}

Fruits, harvested from the above-mentioned mother plants after open pollination, were dried in silica gels at $6{ }^{\circ} \mathrm{C}$. To estimate fertility, 400 seeds per plant were assessed as recommended by the International Seed Testing Administration on the basis of a specific protocol (Van Waes and Debergh 1986), optimized for European orchids as follows: seeds were treated for $6 \mathrm{~h}$ in a solution, consisting of $5 \%(w / v) \mathrm{Ca}(\mathrm{OCl})_{2}$ and $2 \%(v / \mathrm{v})$ Tween-80, and were then soaked in sterile distilled water for $24 \mathrm{~h}$. They were subsequently placed into 2, 3, 5triphenyltetrazolium chloride solution (1 $\mathrm{g}$ substance dissolved in $100 \mathrm{ml}$ sterile distilled water, $\mathrm{pH} \mathrm{7.0)}$ and stored in darkness for $24 \mathrm{~h}$ at $30^{\circ} \mathrm{C}$. Seeds were afterwards rinsed in three changes of sterile distilled water at 5-min intervals, and examined using a stereoscopic microscope. If the embryo showed pink stain it was judged as viable (i.e., fertile seed $=1$ ) with biochemically intact mitochondria, whereas it was judged as unviable (i.e., sterile seed $=0$ ) when it was uncolored or showed reddishyellow colored tissues. Plant-specific seed-fertility rates, lying between 0 and 1 , were obtained after dividing the sum of viable seeds by four hundred. Arithmetic means of seed-fertility rates were calculated using all tested mother plants of a given stand.

It is worthy of note that absolute seed fertilities can only be determined by germination experiments, because the relation of the percentage of germinable seeds to the corresponding percentage of pink-colored seeds is generally unknown. Despite this limitation, embryo-viability stains were successfully employed during the past to identify relative seedfertility differences among Dactylorhiza species and their hybrids (De hert et al. 2012). 
Table 2 Results of pair-wise association tests between populationspecific fitness variables given in the first column and six different Ellenberg's environmental indicator values denoted by F, K, L, N, R, and T. Data from 12 D. majalis populations, which have been studied at the Upper Lusatia region in 2014, were examined

\begin{tabular}{|c|c|c|c|c|c|c|}
\hline $\begin{array}{l}\text { Population-specific fitness } \\
\text { variables }\end{array}$ & Soil moisture F & $\begin{array}{l}\text { Thermal } \\
\text { continentality } \mathrm{K}\end{array}$ & $\begin{array}{l}\text { Light availability } \\
\text { L }\end{array}$ & $\begin{array}{l}\text { Nitrogen content of } \\
\text { the soil } \mathrm{N}\end{array}$ & $\begin{array}{l}\text { pH-reaction of } \\
\text { the soil } \mathrm{R}\end{array}$ & $\begin{array}{l}\text { Ambient } \\
\text { temperatures } \mathrm{T}\end{array}$ \\
\hline & $(95 \%-\mathrm{CI}) \mathrm{p}$ & $(95 \%-\mathrm{CI}) \mathrm{p}$ & $(95 \%-\mathrm{CI}]) \mathrm{p}$ & $(95 \%-\mathrm{CI}) \mathrm{p}$ & $(95 \%-\mathrm{CI}) \mathrm{p}$ & $(95 \%-\mathrm{CI}) \mathrm{p}$ \\
\hline No. of individuals & $\begin{array}{l}0.14 \\
\quad(-0.36 ; 0.58) \\
\quad 0.53\end{array}$ & $\begin{array}{l}-0.35 \\
\quad(-0.78 ; 0.24) \\
\quad 0.13\end{array}$ & $\begin{array}{l}0.38 \\
\quad(-0.04 ; 0.74) \\
\quad 0.09\end{array}$ & $\begin{array}{l}-0.31(-0.78 ; 0.23) \\
\quad 0.17\end{array}$ & $\begin{array}{l}-0.06 \\
\quad(-0.55 ; 0.44) \\
0.78\end{array}$ & $\begin{array}{l}-0.35 \\
\quad(-0.7 ; 0.08) \\
\quad 0.14\end{array}$ \\
\hline No. of flowering individuals & $\begin{array}{l}0.02 \\
\quad(-0.55 ; 0.52) \\
\quad 0.94\end{array}$ & $\frac{-0.5(-0.9 ; 0.09)}{\underline{0.03}}$ & $\begin{array}{l}0.24 \\
\quad(-0.25 ; 0.63) \\
\quad 0.29\end{array}$ & $\begin{array}{l}-0.3(-0.75 ; 0.23) \\
\quad 0.19\end{array}$ & $\begin{array}{l}0.05(-0.45 ; 0.55) \\
\quad 0.83\end{array}$ & $\begin{array}{l}-0.43 \\
\quad(-0.76 ; 0.0) \\
\quad 0.06\end{array}$ \\
\hline $\begin{array}{l}\text { Percentages of flowering } \\
\text { individuals }\end{array}$ & $\begin{array}{l}-0.39 \\
\quad(-0.77 ; 0.09) \\
0.09\end{array}$ & $\begin{array}{l}-0.21(-0.7 ; 0.29) \\
\quad 0.36\end{array}$ & $\begin{array}{l}-0.26 \\
\quad(-0.69 ; 0.26) \\
0.26\end{array}$ & $\begin{array}{l}0.06(-0.57 ; 0.63) \\
\quad 0.78\end{array}$ & $\frac{0.5(0.03 ; 0.81)}{\underline{0.03}}$ & $\begin{array}{l}-0.1 \\
\quad(-0.59 ; 0.41) \\
\quad 0.67\end{array}$ \\
\hline $\begin{array}{l}\text { Average no. of blossoms per } \\
\text { inflorescence }\end{array}$ & $\begin{array}{l}-0.1(-0.7 ; 0.53) \\
\quad 0.67\end{array}$ & $\begin{array}{l}-0.3(-0.78 ; 0.24) \\
0.18\end{array}$ & $\begin{array}{l}-0.16 \\
\quad(-0.59 ; 0.26) \\
\quad 0.49\end{array}$ & $\begin{array}{l}-0.05(-0.69 ; 0.54) \\
\quad 0.83\end{array}$ & $\begin{array}{l}0.28(-0.31,0.78) \\
\quad 0.21\end{array}$ & $\frac{\frac{-0.5}{(-0.91 ; 0.06)}}{\underline{0.03}}$ \\
\hline $\begin{array}{l}\text { Percentages of seed } \\
\text { production }\end{array}$ & $\begin{array}{l}-0.14 \\
\quad(-0.67 ; 0.38) \\
\quad 0.53\end{array}$ & $\begin{array}{l}0.29(-0.22 ; 0.78) \\
\quad 0.21\end{array}$ & $\begin{array}{l}0.06 \\
\quad(-0.37 ; 0.52) \\
0.78\end{array}$ & $\begin{array}{l}0.16(-0.35 ; 0.64) \\
\quad 0.49\end{array}$ & $\begin{array}{l}-0.13 \\
\quad(-0.56 ; 0.32) \\
0.58\end{array}$ & $\frac{0.68(0.19 ; 0.94)}{\underline{0.004}}$ \\
\hline Percentages of seed fertility & $\begin{array}{l}-0.14 \\
\quad(0.59 ; 0.29) \\
0.53\end{array}$ & $\frac{0.6(0.21 ; 0.88)}{\underline{0.008}}$ & $\begin{array}{l}-0.22 \\
\quad(-0.59 ; 0.22) \\
0.33\end{array}$ & $\underline{0.5(0.12 ; 0.88) 0.03}$ & $\begin{array}{l}0.13(-0.35,0.57) \\
\quad 0.58\end{array}$ & $\begin{array}{l}-0.05 \\
\quad(-0.55 ; 0.47) \\
\quad 0.83\end{array}$ \\
\hline
\end{tabular}

Data are presented as Kendall's correlation coefficient , with bootstrapped $95 \%$ confidence intervals in brackets (10,000 replicates) and corresponding $p$ values. Note that bootstrapped confidence intervals may include 0.0 , due to ties. Underlined values indicate significant findings. $(\mathrm{CI}=$ confidence interval; $p=p$ value)

\section{Environmental assessment}

Plant species, forming the habitat communities, were identified by utilizing a current version of Rothmaler's morphologic key (Jäger 2011). For this purpose, a restricted area of $225 \mathrm{~m}^{2}$ was inspected per location. Each species is known to meet specific environmental conditions within its range of distribution, i.e., soil moisture $(\mathrm{F})$, thermal continentality $(\mathrm{K})$, light availability (L), nitrogen content of the soil $(\mathrm{N})$, pH-reaction of the soil (R), and ambient temperatures (T) as has been documented by Ellenberg's indicator values (Ellenberg et al. 1992).

We summarized all identified plant species at a given stand and calculated unweighted arithmetic means for each of the above-mentioned indicator value. Finally, the degree of correlation was tested between the obtained means of site-specific indicator values and population-specific fitness parameters in the ensuing exploratory statistical data analysis (see below).

\section{Data analysis}

The following procedures were conducted in statistics and population genetics: I, pair-wise correlation analyses among fitness variables assessing sexual reproduction and with genetic diversity measures (see below); II, pair-wise exploratory statistical analyses among fitness data and environmental indicator values by estimating Kendall's correlation coefficient
(Kendall 1955); III, analyzing the frequency distribution of the present embryo-viability classes over all stands by a histogram; IV, Ward's agglomerative hierarchical clustering method (Ward 1963) and non-hierarchical $k$-means clustering in conjunction with a scree test to dissect the investigated populations according to their seed fertilities; V, nonparametric H tests (Kruskal and Wallis 1952) comparing non-Gaussian seed-fertility distributions over all 12 stands as a whole and over all stands within a given identified seedfertility cluster; VI, chi-squared independence tests to evaluate associations between seed-fertility clusters and genotypes of each investigated marker, taking together minor genotypes of individual frequencies $\leq 5 \%$ (Sham and Curtis 1995); in the case of a significant association, multiple Fisher's exact tests, as discussed by McDonald (2014), were used to identify the microsatellite genotypes responsible for the association; VII, exact Mann-Whitney U (MWU) tests (Mann and Whitney 1947) in the case of two clusters, or $\mathrm{H}$ tests in the case of more than two clusters, to assess differences in seed fertilities and indicator values between the genetically distinct fertility clusters previously identified. All above-mentioned analyses were run by the software package $R$ (R Core Team 2017). Confidence intervals for Kendall's were computed by the $R$ package NSM3 (Hollander et al. 2015). Calculating exact MWU tests with corresponding confidence intervals was done by the $R$ package coin (Hothorn et al. 2006). 
Using POPGENE version 1.31 (F. C. Yeh, R. Yang and T. Boyle, University of Alberta and Centre for International Forestry Research, Canada, 1999), allele frequencies as well as both single- and two-locus genotype frequencies were computed for all three microsatellite markers and all investigated populations to estimate number of alleles $\left(N_{A}\right)$, number of genotypes $\left(N_{G}\right)$, observed heterozygosity $\left(H_{o}\right)$, expected heterozygosity $\left(H_{e}\right), F$-statistics $\left(F_{S T}, F_{I S}\right.$, and $\left.F_{I T}\right)$, genetic distances, and disequilibria measures according to Wright (1978), Nei (1972, 1973), and Smouse et al. (1983), respectively. Departures from HWE were tested for each marker and each population by the $R$ package genetics (Warnes 2013). To calculate the diversity for alleles $\left(V_{A}\right)$, as defined by Gregorius $(1978,1987)$, we employed the GSED computer software version 3.0 (E. M. Gillet, University of Goettingen, Germany, 2010).

All $p$ values $\leq 0.05$ were considered statistically significant. $P$ values of the statistical procedures given in method II and V were not adjusted for multiple testing due to the exploratory character of the analyses. P values of the statistical operations described by methods I, VI, VII, disequilibria measures, and HWE tests were adjusted for multiple examinations by Bonferroni-Holm correction (Holm 1979).

\section{Results}

\section{Fitness variables assessing sexual reproduction}

We registered small populations, sparsely settled with several dozens of $D$. majalis plants, as well as more abundant populations where hundreds and in four cases even more than thousand individuals of this taxon appeared (Tab. 1). Population no. 3 is an exception with 8000 D. majalis plants. Over all stands, flower formation was observed in May for $16.4 \%$ to $89.8 \%$ of the growing individuals, which provided on average 13 to 32 blossoms per inflorescence (Tab. 1). On average, $31.1 \%$ through to $69.3 \%$ of the enumerated flowers were found to produce fruits later-on (Tab. 1). It should be noted, however, that for unknown reasons a certain number of the originally detected flowering plants or their seeds disappeared in the nature before the assessment of fruit-set took place. This phenomenon is of major concern to small populations (compare the fourth column vs. the fifth column in Tab. 1). Moreover, extremely high rates of seed sterilities were recorded from all 12 study populations, because only a minority of a total sum of 85,600 analyzed embryos were able to demonstrate viability (ranging from $4.24 \%$ to $16.41 \%$ on average per stand as shown in Tab. 1). We found no significant correlation among the above-mentioned fitness variables, except for the strong correlation $(\mathrm{r}=0.965 ; p=0.00000364)$ identified between the absolute numbers of growing and flowering individuals.

\section{Cytological studies illustrating aberrant meiosis}

The intimate structure of chromosomes in developing megasporocytes was recorded under the microscope for six D. majalis plants of population no. 9, which were collected in April 2017 and 2018. As a result, some erratic arrangements (i.e., large ring-shaped conjugations of more than two chromosomes, a fragile equatorial zone in germinal cells, a sortingout of single chromosomes, and microcytes possessing the small number of remaining chromosomes) were observed at different time points during both meiotic divisions (Fig. 2). Such irregularities can cause aneuploid chromosome numbers with respect to the produced female gametes and can therefore likely explain the high amount of sterile seeds previously determined during the growing season in 2014 (see above).

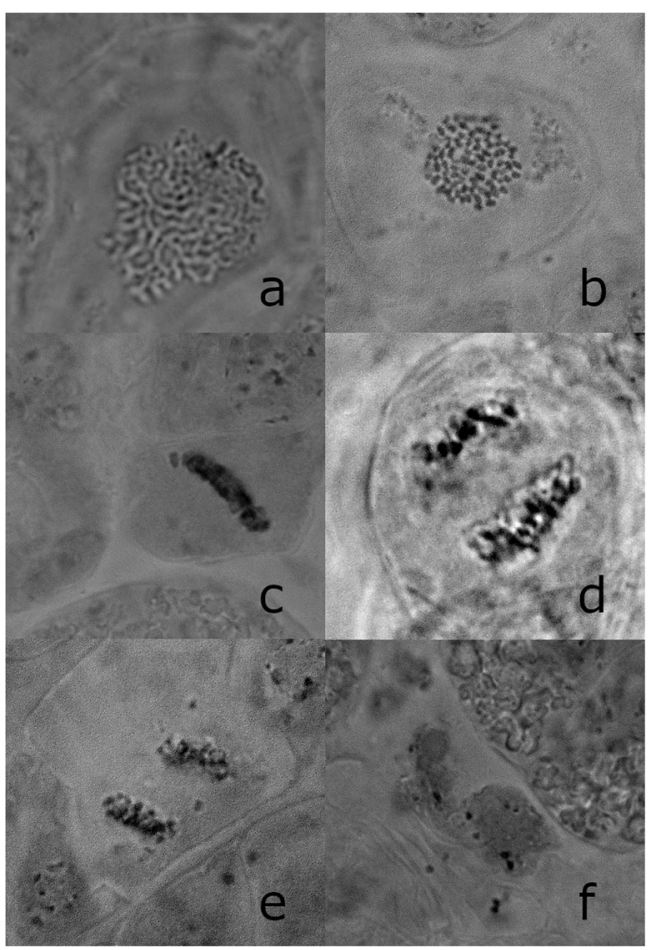

Fig. 2 Erratic megasporogenesis in D. majalis. a Prophase I indicates unusual ring-shaped conjugations assembled by more than two chromosomes and their chiasmata; b Metaphase I shows the unreduced chromosome complement, where only 78 of the 80 expected chromosomes are discernible; $\mathbf{c}$ Ruptures taking place at both margins of the equatorial zone initiate a local separation of single chromosomes; d The majority of chromosomes migrates poleward in anaphase I, but distinct chromosomes remain in the equatorial zone as indicated for the upper spindle machinery; e Telophase I illustrates an assortment of single chromosomes from the greater part of chromosomes resting in the cytoplasm; f Microcytes possessing an irregular small number of chromosomes in the second meiotic division result from the above-mentioned disorders seen in the first division. (1000x microscopic magnification; acetocarmine smears) 


\section{Exploratory statistical analysis aggregating fitness data and environments}

We compared the above-mentioned fitness variables from 12 D. majalis stands to six environmental indicators. As can be seen by Kendall's correlation coefficient (Tab. 2), positively true (i.e., direct) associations were detected between the percentages of flowering $D$. majalis individuals and $\mathrm{pH}$-reaction of the soil (R), between the percentages of their seed production and ambient temperature (T), between the percentages of their seed fertility and thermal continentality $(\mathrm{K})$ as well as between the percentages of their seed fertility and nitrogen content of the soil $(\mathrm{N})$. Negatively true (i.e., reciprocal) associations were discovered between the number of flowering D. majalis individuals and thermal continentality $(\mathrm{K})$ as well as between the average number of blossoms per inflorescence and the ambient temperature (T).

\section{Agglomerative cluster analysis detecting two seed-fertility groups in differing environments}

Inspecting all plant-specific highly variable embryo viabilities, which displayed a L-shaped non-Gaussian frequency distribution (Fig. 3), the $\mathrm{H}$ test revealed significant differences among the stands (chi-squared $=40.516 ; p=0.000029$ ). Treating this data by Ward's agglomerative hierarchical clustering method, two distinct fertility groups were identified (Fig. 4; upper part). Cluster I unified the samples of population nos. $1,6,8,9,10$ and 11 due to their superior seed fertilities

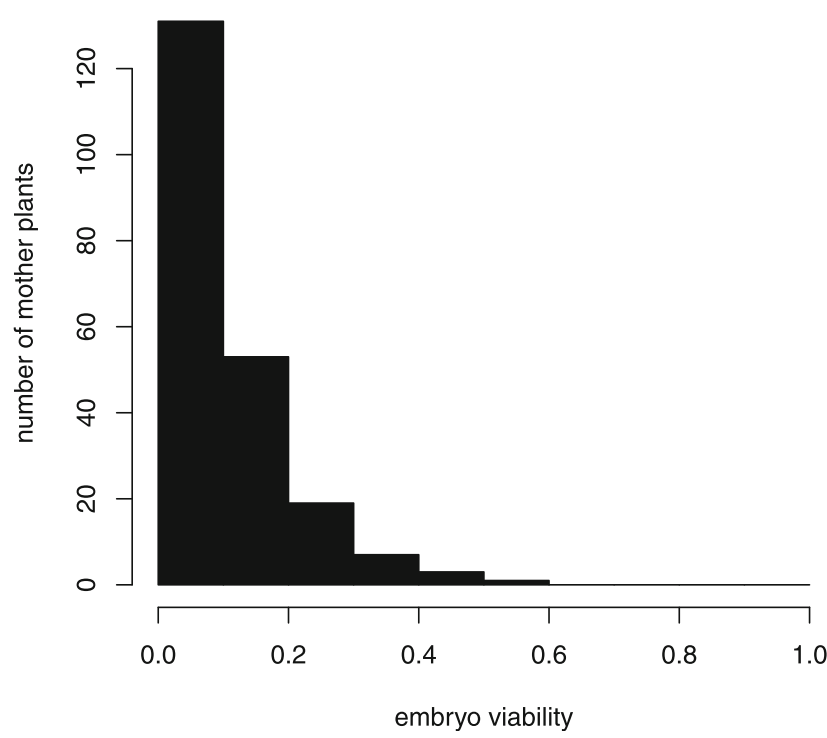

Fig. 3 Histogram illustrating the frequency distribution of different embryo viability classes among 12 studied populations of D. majalis. Embryo viability was dissected in six classes, as shown by the rectangles, ranging from 0.0 (i.e., $0 \%$ of the embryos were alive) to 0.6 (i.e., $60 \%$ of the embryos were alive). Heights of the rectangles are equal to the number of mother plants representing each class. Data were obtained from 400 seeds per mother plant using arithmetic means
( $12.88 \%-16.41 \%$ on average). Cluster II harbored the seed samples of population nos. 2, 3, 4, 5, 7 and 12, which shared very poor fertilities ranging from $4.24 \%$ to $9.04 \%$. The marked bipartite classification was strongly supported by the present knee in the $k$-means graph (Fig. 4; lower part), which indicated that the calculated residual sum of squares did not substantially decrease when dissecting seed fertility data in greater numbers of clusters. Performing the $\mathrm{H}$ test procedure, no significant fertility differences were detectable whether within cluster I (chi-squared $=1.3035 ; p=0.9346$ ) nor within cluster II (chi-squared $=8.0358 ; p=0.1543$ ). This underpins the similarity of fertility data within each identified cluster. However, significant differences $(p<0.0001)$ were apparent between both clusters when the seed-fertility data were subjected to the MWU test. Further, the results of additional MWU tests assessing differences in each of the six Ellenberg's indicator values between the orchid stands in seed-fertility cluster I and II can be found in Table 3. As illustrated by the calculated Hodges-Lehmann estimators, the two fertility clusters differed considerably in their thermal continentality, but not in any other assessed environmental indicator. The marked difference in thermal continentality between the two clusters is expressed by the fact that with reference to cluster I enhanced $\mathrm{K}$ values of 3.5, 3.6, 3.7, 3.7, 3.6 and 3.5 were registered for the thermal environments of population nos. 1, 6, 8, 9, 10 and 11, respectively. Concerning cluster II, reduced $\mathrm{K}$ values of 3.5, 3.0, 3.3, 3.4, 3.4 and 3.2 were on the other hand provided by population nos. $2,3,4,5$, 7 and 12 , respectively.

\section{DNA marker data demonstrating genetic variability in association with both fertility clusters}

Conducting genetic inventories by three nuclear-encoded microsatellites, we recorded a total of 23 alleles and 39 genotypes out of 271 examined mother plants (Tab. 4). Locus ms14 was the most polymorphic, showing a diversity for alleles spanning over all stands from 1.88 to 3.39 with a number of genotypes reaching from 2 through to 9 . Values were a little bit lower for markers $\mathrm{ms} 13$ and $\mathrm{ms} 3$ with a diversity for alleles spanning from 1.88 to 2.90 and from 1.52 to 2.76 , respectively, and with a number of genotypes ranging from 3 to 8 . No tested allelic or genotypic diversity parameter $\left(N_{A}, N_{G}, V_{A}, H_{o}\right.$, and $H_{e}$ ) was found to be in linear correlation with the absolute numbers of growing individuals or the relative seed-fertility rates provided by the populations (data not shown). With respect to the $F$-statistics $\left(F_{I S}\right.$ and $F_{I T}$, Tab. 4$)$, heterozygote deficits reaching from $7 \%$ to $13 \%$ in the case of loci $\mathrm{ms} 3$ and $\mathrm{ms} 14$ were detected, whereas locus $\mathrm{ms} 13$ revealed an opposite excess of $11 \%$ to $18 \%$ heterozygotes over all stands. Yet, statistically significant deviations from HWE were not observed except for the homozygosity excesses measured for marker ms14 in population nos. $5(p=0.0238)$ and 9 
Fig. 4 Dendrogram (upper part) displaying the results of a hierarchical agglomerative cluster analysis on the basis of Ward's algorithm. The received seed fertilities of mother plants of 12 D. majalis populations (their identification numbers are given in brackets with reference to Fig. 1; S.dorf $=$ Seifhennersdorf) were merged into two different fertility clusters as indicated by horizontal lines and the Manhattan distance metric attributed to the $y-$ coordinate. The two-cluster solution was underpinned by a scree test (lower part of the figure) as calculated from the residual sum of squares of a nonhierarchical k-means cluster analysis and a variable number of clusters ranging from 1 to 11 . A corresponding scree test leaving out the 1-cluster solution was inconclusive. The two clusters of the hierarchical cluster analysis were the same as in the k-means analysis

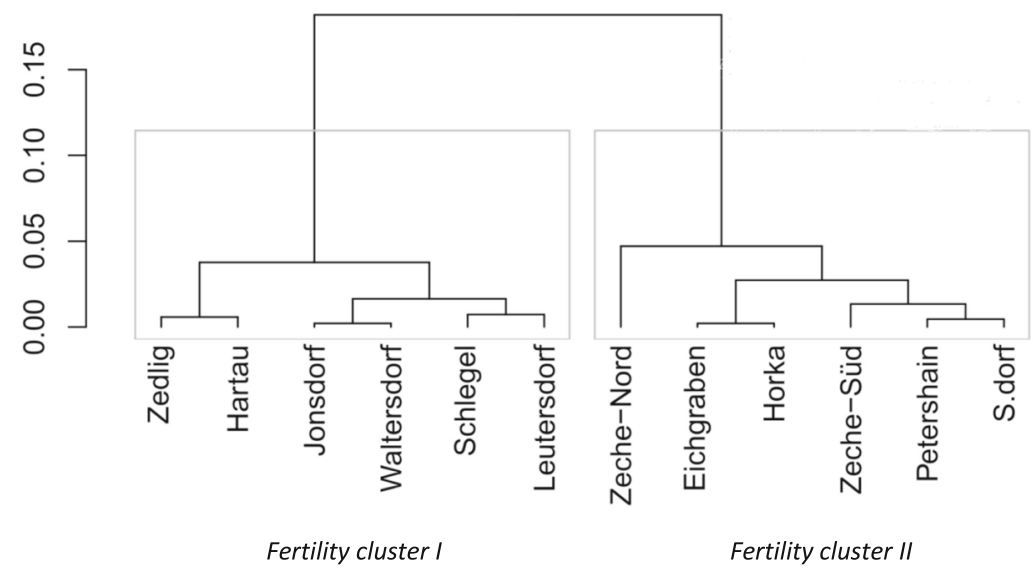

(1)
(8)
(9)
(10) (6)
(11)
(3) (7)
(5)
(4) (2)

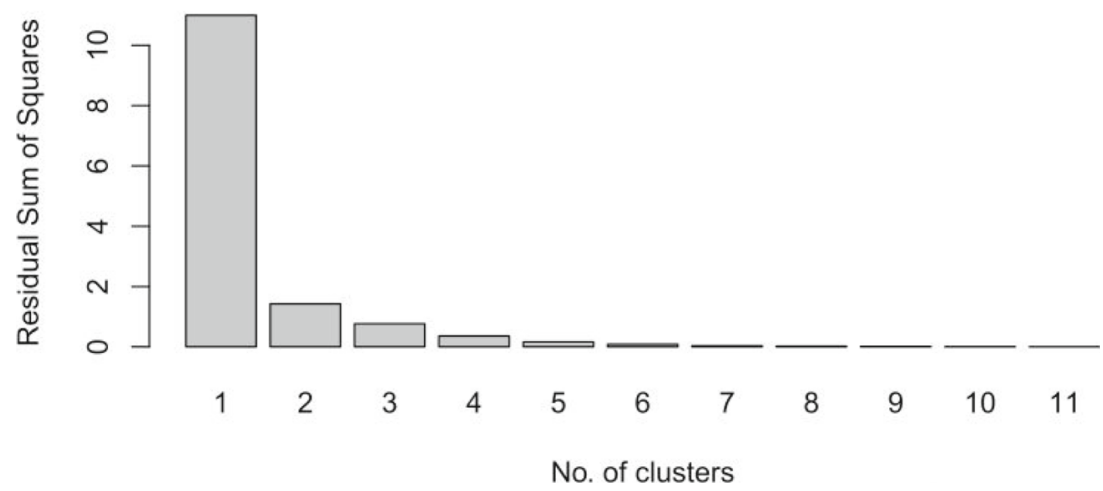

$(p=0.0140$ ), and both the homozygosity and heterozygosity excesses $(p=0.0036)$ associated with marker ms 13 in population no. 5 (Tab. 4). A moderate $6 \%$ among-population genetic differentiation was inferred from all three locus-specific $F_{S T}$ values (Tab. 4). Pair-wise comparisons of Nei's genetic distances, calculated for each marker locus, did not very well reflect the geographic relationships among all 12 studied locations. Specifically, geographically nearby populations (e.g. populations nos. 9 and 10, lying $5 \mathrm{~km}$ apart from each other) mostly did not cluster together based on genetic distances, whereas distant populations (e.g. populations no. 3 and 6 , lying $57 \mathrm{~km}$ apart from each other) often clustered together based on genetic distances. There was, however, an informative allele frequency variation for alleles $\mathrm{D}$ and $\mathrm{E}$ of marker locus ms14 in a clinal fashion when comparing all populations (i.e., allele D dominated among the majority of mother plant populations bearing reduced embryo viabilities, whereas allele E controlled the more fertile test populations). Resulting from this diagonal line of direction, a remarkable non-random association concerning the

Table 3 Results of exact Mann-Whitney $U$ tests evaluating differences in local site conditions between the two previously identified fertility clusters, based on embryo-viability stains. Ellenberg's indicator values

F, K, L, N, R, and T were calculated to assess environmental site conditions. All calculations were done during the growing season 2014

\begin{tabular}{|c|c|c|c|c|c|c|}
\hline & Soil moisture F & $\begin{array}{l}\text { Thermal } \\
\text { continentality K }\end{array}$ & Light availability L & $\begin{array}{l}\text { Nitrogen content } \\
\text { of the soil } \mathrm{N}\end{array}$ & $\begin{array}{l}\mathrm{pH}-\text {-reaction } \\
\text { of the soil R }\end{array}$ & $\begin{array}{l}\text { Ambient } \\
\text { temperatures } \mathrm{T}\end{array}$ \\
\hline \multirow[t]{2}{*}{ p value Hodges-Lehmann estimator } & 1.0 & $0.039^{*}$ & 1.0 & 0.42 & 1.0 & 1.0 \\
\hline & -0.05 & $0.3 *$ & -0.1 & 0.4 & 0.1 & -0.1 \\
\hline$(95 \%-C I)$ & $(-0.6 ; 0.7)$ & $(0.1 ; 0.5)^{*}$ & $(-0.4 ; 0.2)$ & $(-0.2 ; 0.7)$ & $(-0.6 ; 0.7)$ & $(-0.2 ; 0.2)$ \\
\hline
\end{tabular}

Bonferroni-Holm corrected $\mathrm{p}$ values are shown in the first data line. The sizes of the detected differences were assessed by the Hodges-Lehmann estimators (Hodges and Lehmann 1963) given in the second data line, with bootstrapped $95 \%$ confidence intervals (95\%-CI) printed in brackets when performing 10,000 replicates. Significant differences of site conditions between fertility groups I and II are marked by a star symbol 
Table 4 List of allelic and genotypic data derived from three microsatellite markers of mother plants of 12 D. majalis populations. The used leaf material was sampled in the Upper Lusatia region during the growing season 2014

Microsatellite Identified alleles Frequency distribution of all identified genotypes with respect to the given population nos.

\begin{tabular}{|c|c|c|c|c|c|c|c|c|c|c|c|c|c|}
\hline & \multirow{2}{*}{$\begin{array}{l}\text { over all } \\
\text { populations }\end{array}$} & \\
\hline & & 1 & 2 & 3 & 4 & 5 & 6 & 7 & 8 & 9 & 10 & 11 & 12 \\
\hline \multirow[t]{9}{*}{ ms3 } & $\begin{array}{c}\text { A [130]; B } \\
\text { [148]; }\end{array}$ & $\mathrm{DD}(4)$ & $\mathrm{DD}(3)$ & $\mathrm{DD}(1)$ & $\mathrm{DD}(3)$ & $\mathrm{DD}(1)$ & $\mathrm{DD}(1)$ & $\mathrm{DD}(1)$ & $\mathrm{DD}(2)$ & $\mathrm{DD}(3)$ & $\operatorname{DG}(8)$ & $\mathrm{DD}(3)$ & $\mathrm{CD}(1)$ \\
\hline & $\begin{array}{c}\text { C [154]; D } \\
\quad[157] ;\end{array}$ & $\mathrm{DF}(1)$ & $\mathrm{DF}(1)$ & $\mathrm{DF}(1)$ & $\mathrm{FF}(2)$ & DG(3) & $\mathrm{DF}(6)$ & $\mathrm{EE}(2$ & DG(9) & DG(5) & $\mathrm{FG}(2)$ & $\mathrm{DG}(6)$ & CG(1) \\
\hline & E [160]; F [163]; & $\mathrm{FF}(2)$ & $\mathrm{BG}(1)$ & $\mathrm{AG}(2)$ & DG(10) & $\mathrm{FG}(3)$ & DG(7) & DG(4) & GG(13) & GG(17) & GG(13) & $\mathrm{FG}(1)$ & DG(5) \\
\hline & G [166]; H [169] & $\mathrm{AG}(1)$ & DG(7) & $\mathrm{DG}(1)$ & $\mathrm{FG}(2)$ & GG(15) & $\mathrm{FG}(4)$ & $\mathrm{EG}(3)$ & & & & GG(11) & FG(4) \\
\hline & & GD(10) & $\mathrm{FG}(1)$ & $\mathrm{FG}(3)$ & GG(6) & $\mathrm{GH}(2)$ & GG(5) & GG(11) & & & & & $\mathrm{GG}(7)$ \\
\hline & & $\mathrm{GF}(1)$ & GG(10) & GG(14) & & & & & & & & & \\
\hline & & GG(4) & & & & & & & & & & & \\
\hline & & $\mathrm{GH}(1)$ & & & & & & & & & & & \\
\hline & & $F S T=0$. & 0615, FIS & $S=0.0738$ & , FIT $=0$ & .1307 & & & & & & & \\
\hline \multirow[t]{9}{*}{$\mathrm{ms} 13$} & A [91]; В [94]; & $\mathrm{AA}(1)$ & $\mathrm{AB}(10)$ & $\mathrm{AB}(9)$ & $\mathrm{AA}(1)$ & $\mathrm{AB}(1)$ & $\mathrm{AB}(11)$ & $\mathrm{AB}(6)$ & $\mathrm{AA}(3)$ & $\mathrm{AA}(3)$ & $\mathrm{AA}(1)$ & $\mathrm{AB}(10)$ & $\mathrm{AA}(4)$ \\
\hline & C [97]; D [100]; & $\mathrm{AB}(10)$ & $\mathrm{BB}(3)$ & $\mathrm{BB}(6)$ & $\mathrm{AB}(10)$ & $\mathrm{BB}(7) \boldsymbol{\Lambda}$ & $\mathrm{BB}(6)$ & $\mathrm{AE}(8)$ & $\mathrm{AB}(9)$ & $\mathrm{AB}(9)$ & $\mathrm{AB}(4)$ & $\mathrm{BB}(4)$ & $\mathrm{AB}(5)$ \\
\hline & E [103]; F [112]; & $\mathrm{BB}(2)$ & $\mathrm{AE}(2)$ & $\mathrm{BE}(2)$ & $\mathrm{BB}(5)$ & $\mathrm{BC}(1) \square$ & $\mathrm{AE}(1)$ & $\mathrm{BE}(1)$ & $\mathrm{BB}(1)$ & $\mathrm{BB}(3)$ & $\mathrm{BB}(8)$ & $\mathrm{AC}(1)$ & $\mathrm{BB}(5)$ \\
\hline & $\mathrm{G}[115]$ & $\mathrm{AE}(1)$ & & & $\mathrm{AC}(2)$ & $\mathrm{AE}(2)$ & $\mathrm{BE}(3)$ & & $\mathrm{AE}(4)$ & $\mathrm{AC}(3)$ & $\mathrm{AE}(3)$ & $\mathrm{AE}(1)$ & $\mathrm{BC}(1)$ \\
\hline & & & & & $\mathrm{BC}(1)$ & $\mathrm{BE}(3)$ & & & $\mathrm{BE}(4)$ & $\mathrm{AE}(4)$ & $\mathrm{BE}(5)$ & $\mathrm{BE}(3)$ & $\mathrm{AE}(2)$ \\
\hline & & & & & $\mathrm{CC}(1)$ & $\mathrm{EE}(3) \boldsymbol{\Lambda}$ & & & $\mathrm{EE}(2)$ & & $\mathrm{EE}(1)$ & $\mathrm{DE}(1)$ & $\mathrm{BE}(3)$ \\
\hline & & & & & $\mathrm{AA}(1)$ & $\mathrm{FG}(1)$ & & & & & & $\mathrm{EE}(1)$ & \\
\hline & & & & & $\mathrm{EE}(1)$ & & & & & & & & \\
\hline & & $F S T=0$. & 0611, FIS & $=-0.177$ & $8, F I T=-$ & -0.1058 & & & & & & & \\
\hline \multirow[t]{10}{*}{ ms14 } & $\begin{array}{c}\text { A [268]; B } \\
\text { [279]; }\end{array}$ & $\mathrm{BD}(1)$ & $\mathrm{BD}(2)$ & $\mathrm{BD}(1)$ & $\mathrm{DD}(2)$ & $\mathrm{AA}(1) \boldsymbol{\Delta}$ & $\mathrm{BD}(4)$ & $\mathrm{DD}(11)$ & $\mathrm{DD}(6)$ & $\mathrm{BB}(1) \boldsymbol{\Delta}$ & $\mathrm{DD}(2)$ & $\mathrm{DD}(6)$ & $\mathrm{DD}(5)$ \\
\hline & $\begin{array}{l}\text { C [285]; D } \\
\quad[288] ;\end{array}$ & $\mathrm{DD}(3)$ & $\mathrm{DD}(9)$ & $\mathrm{CD}(1)$ & $\mathrm{DE}(6)$ & $\mathrm{BB}(1) \boldsymbol{\Delta}$ & $\mathrm{DD}(7)$ & $\mathrm{DE}(6)$ & $\mathrm{DE}(8)$ & $\mathrm{DD}(4) \boldsymbol{\Lambda}$ & $\mathrm{DE}(13)$ & $\mathrm{DE}(8)$ & $\mathrm{DE}(13)$ \\
\hline & E [291]; F [294]; & $\mathrm{BE}(4)$ & $\mathrm{DE}(4)$ & $\mathrm{DD}(3)$ & & $\mathrm{BD}(1)$ & $\mathrm{DE}(5)$ & $\mathrm{EE}(1)$ & $\mathrm{EE}(9)$ & $\mathrm{BE}(1)$ & $\mathrm{EE}(3)$ & $\mathrm{EE}(4)$ & DG(3) \\
\hline & G [297]; H [300] & $\mathrm{DE}(6)$ & $\mathrm{EE}(3)$ & $\mathrm{BE}(1)$ & & $\mathrm{DD}(8) \boldsymbol{\Lambda}$ & $\mathrm{EE}(8)$ & $\mathrm{DF}(5)$ & $\mathrm{EG}(1)$ & $\mathrm{DE}(6)$ & $\mathrm{EF}(1)$ & $\mathrm{EF}(1)$ & GG(1) \\
\hline & & $\mathrm{EE}(4)$ & $\mathrm{DF}(3)$ & $\mathrm{DE}(9)$ & & $\mathrm{BE}(1)$ & & $\mathrm{FF}(1)$ & & $\mathrm{EE}(10) \boldsymbol{\Lambda}$ & & $\mathrm{FF}(2)$ & \\
\hline & & $\mathrm{DF}(1)$ & DG(1) & $\mathrm{EE}(3)$ & & $\mathrm{DE}(3)$ & & & & $\mathrm{DG}(1)$ & & $\mathrm{EG}(1)$ & \\
\hline & & $\mathrm{EF}(3)$ & & $\mathrm{DF}(1)$ & & $\mathrm{EE}(4) \boldsymbol{\Delta}$ & & & & $\mathrm{GG}(2) \boldsymbol{\Delta}$ & & $\mathrm{EH}(1)$ & \\
\hline & & $\mathrm{FF}(1)$ & & $\mathrm{EF}(1)$ & & $\mathrm{EF}(2)$ & & & & & & & \\
\hline & & & & $\mathrm{DG}(2)$ & & $\mathrm{FF}(3) \boldsymbol{\Delta}$ & & & & & & & \\
\hline & & $F S T=0$. & 0592, FIS & $S=0.0779$ & $F I T=0$ & .1324 & & & & & & & \\
\hline
\end{tabular}

Sizes of PCR products are indicated in base-pairs and printed in brackets [] for all identified alleles (named A-H). Genotypes are reported for each population, with the number of corresponding plants given in parentheses (). Triangle symbols mark significant homozygosity excess and square symbols mark significant heterozygosity excess of genotypes compared to expected values assuming HWE (adjusted $p \leq 0.05$ ). The level of genetic differentiation within and among the stands is displayed for each single marker locus at the bottom line by the corresponding F-statistics $\left(\mathrm{F}_{\mathrm{ST}}, \mathrm{F}_{\mathrm{IS}}\right.$, and $\left.\mathrm{F}_{\mathrm{IT}}\right)$

opposite frequency distribution of the prominent genotypes EE and DD was identified for marker ms14, which exactly corresponds to both seed-fertility clusters mentioned above (for detailed information see Fig. 5 and its legend). Testing multilocus departures from panmictic equilibrium, a non-random union of gametes was exclusively found in the case of population no. 7 with respect to two pairs of loci, namely between locus ms 13 and locus ms14 $(p=0.0024)$ as well as between locus ms3 and locus ms13 $(p=0.0414)$, respectively.

\section{Discussion}

\section{Differential seed fertilities and the detected meiotic irregularities}

In this study, we found that the orchid hybrid D. majalis exhibits a mosaic of differential fertility among the seeds, including a high number of inviable embryos, which corresponds well to the data previously released by other investigators (De hert et al. 2012). This probably resulted from the 


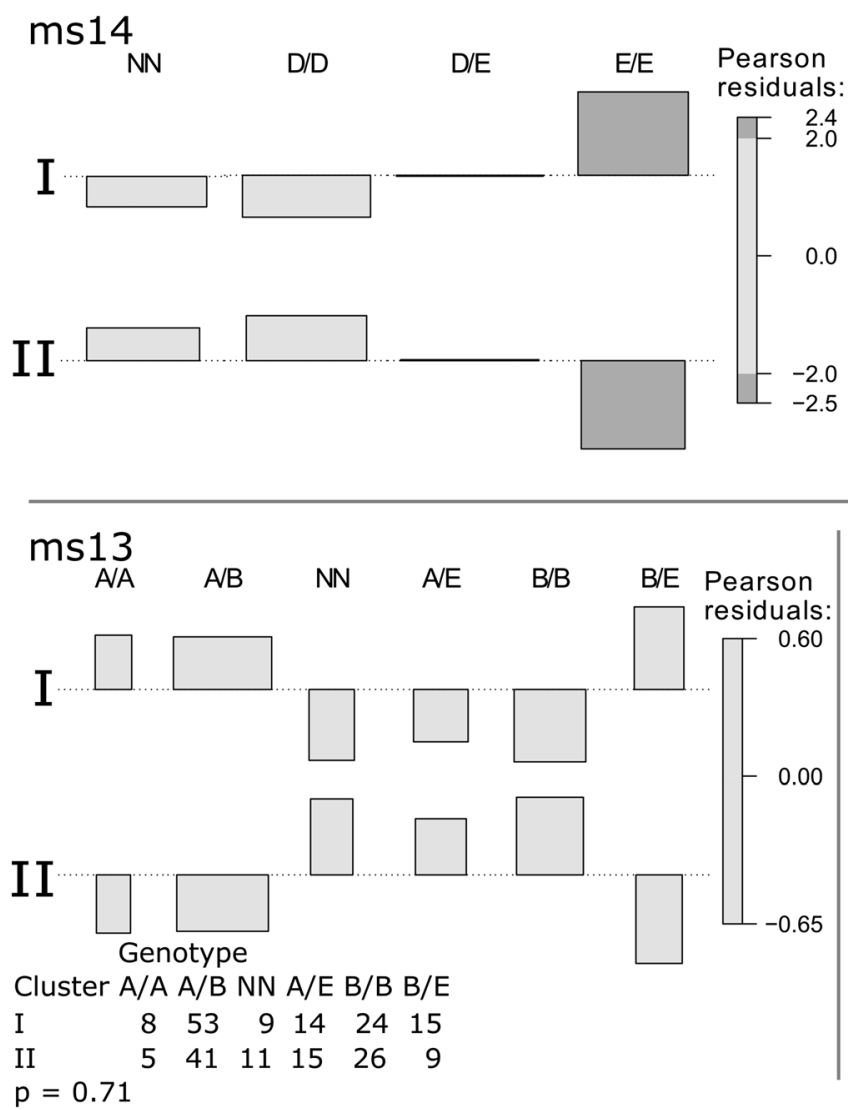

Fig. 5 Association plot illustrating the chi-squared independence tests of both fertility clusters (named I and II) with microsatellite marker genotypes $\mathrm{ms} 3$, ms 13 , and ms14. Genotypes with frequencies $\leq 0.05$ were pooled together in genotype class "NN". The contingency table with corresponding $p$ value for the chi-squared test is given below each association plot. In the association plot, each cell is represented by a rectangle that has signed height proportional to the signed contribution to the chisquared test statistic, i.e., the difference between observed and expected counts divided by the square root of the expected counts, and width proportional to the square root of the expected counts, so that the area of the box is proportional to the difference in observed and expected

irregular chromosome pairing, which we detected by examining a few megasporocytes. Considering the large rings of multivalent chromosome pairs recorded (normally only rodshaped bivalents should be observed), frequent translocations among them are argued to remove centromere-linked regions from single chromosomes by unequal crossover. As a consequence of such deletions, the affected chromosomes cannot properly make contact with the spindle machinery during both meiotic divisions. Hence, they will be sorted out as furthermore discovered by our analyses, resulting later-on in aneuploid germ-cells and contributing to a reduced fertility among heterozygous offspring as reviewed by Futuyma (1986). Differences in the heterochromatin content, resulting from repetitive non-coding sequences, with pronounced effects on meiotic recombination have been already assumed to control chromosomal stability during tissue cultivation and plant regeneration (Karp 1994).
Multiple comparisons using Fisher's exact tests

Bonferroni-Holm corrected $p$ values

$\begin{array}{llll} & \mathrm{D} / \mathrm{D} & \mathrm{D} / \mathrm{E} & \mathrm{E} / \mathrm{E} \\ \mathrm{NN} & 0.86 & 0.80 & \mathbf{0 . 0 0 4} \\ \mathrm{D} / \mathrm{D} & & 0.76 & \mathbf{0 . 0 0 2} \\ \mathrm{D} / \mathrm{E} & & & \mathbf{0 . 0 2 3}\end{array}$

Genotype

Cluster NN D/D D/E E/E

$\begin{array}{lllll}\text { I } & 26 & 28 & 46 & 38\end{array}$

II $\quad \begin{array}{llll}32 & 38 & 41 & 11\end{array}$

$\mathrm{p}<0.001$

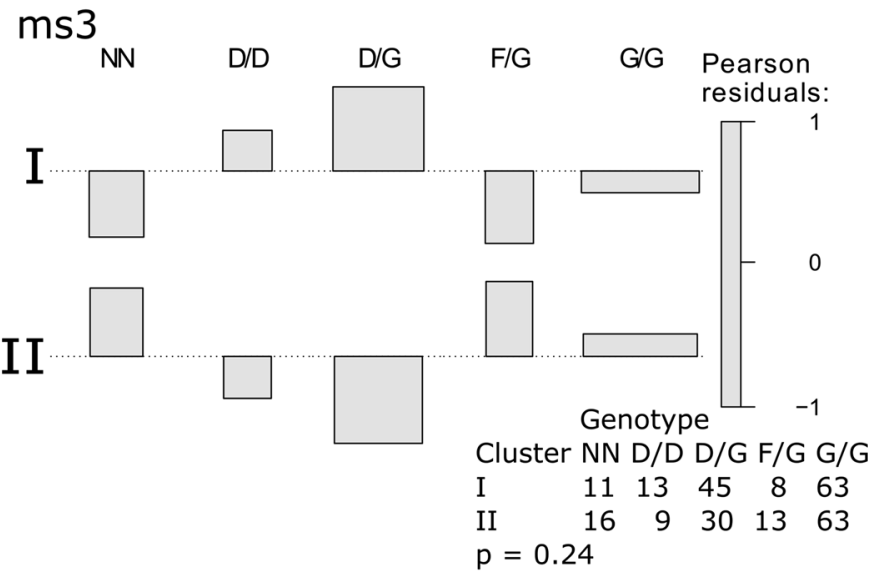

frequencies (see Friendly 1992; Meyer et al. 2003). The rectangles in each row are positioned relative to a baseline indicating independence (no difference between observed and expected counts). If the observed genotype frequency of a cell is greater than the expected one, the box rises above the baseline, and falls below otherwise. In addition, signed contributions to the chi-squared test statistic (Pearson residuals) are colored according to the legend given for each subfigure (darkgrey: $\geq 2$ ). For marker ms14, multiple comparisons using exact Fisher's tests are furthermore shown (upper panel, right). Figures in bold indicate $p$ values $\leq 0.05$. The plot was created using the $R$ package $v c d$ (Meyer et al. 2006, 2017; Zeileis et al. 2007)

In fertile allotetraploid hybrids, two different diploid genomes of exactly the same chromosomal number are combined as outlined by Comai (2005). At meiosis, the chromosomes of both contributors segregate equally but independently into the four germ-cells since homogeneic pairing is enforced between homologous chromosomes of the same origin. This prevents intergenomic recombination and maintains the benefits of heterosis. By contrast, if there is a single unpaired chromosome (aneuploidy), moving to one or to the other cell pole, and/or heterogeneic pairing takes place between both species constituents (this is likely the case regarding the multivalent conjugations of more than two chromosomes seen in Fig. 2), subsequent generations are affected by a reduced fertility. Extraordinary heterogeneic recombination between structurally related chromosomes of both contributors is on the other hand acknowledged to be an 
advantageous evolutionary force possibly enabling D. majalis to adapt to changing environments (Hedrén 1996).

\section{Continental climate stress, sexual reproduction and local adaptation}

We discovered for D. majalis marked bipartite patterns of seed fertility in correlation with different climatic environments relying on the Ellenberg's thermal continentality indicator value (Ellenberg et al. 1992). In Upper Lusatia, winters are a little bit longer and colder, and summers are a little bit shorter and warmer compared to western Germany. This is due to a substantial continental climate impact in East Saxony (for general information see Weischet and Endlicher 2000; Kondratyev et al. 2002), which is reflected by relatively high thermal continentality indicator values spanning from 3.2 to 3.7 for 11 out of 12 studied populations. Only population no. 3 met a thermal continentality indicator value of 3 , which suggests an optimal environment for D. majalis (Ellenberg et al. 1992). In line with the original observation by Ellenberg and coworkers (Ellenberg et al. 1992) that central European stands of D. majalis do not perform well when reproducing under harsh continental conditions, we detected a reciprocal statistical association between the absolute numbers of flowering individuals and increasing thermal continentality. This was supported by the fact that rising ambient temperatures lowered the average number of blossoms per inflorescence. Both phenomena, conflicting with sexual reproduction, were surprisingly compensated by a higher seed fertility in unpleasant environments to avoid local extinction. For comparison, recent investigations previously demonstrated that deceptive orchid species in Central Europe, depending on naive pollinators because not offering nectar, can increase their reproductive success by higher seed numbers in the face of a pollinator limitation (Sonkoly et al. 2015). For an exact taxonomic identification of $D$. majalis pollinators and the floral chemical compounds attracting such insects, see Ostrowiecka et al. (2019) and Wróblewska et al. (2019), respectively, and the literature cited therein.

Other fitness variables provided by our investigation, e.g., high relative fruit-building rates, were in accordance with the results released by Sonkoly et al. (2015), but were opposed to those by Claessens and Kleynen (2011). Since the mean fruitset of deceptive orchids was found to be only $27.7 \%$ (Neiland and Wilcock 1998), whereas we registered in mean from 31.1 $\%$ to $69.3 \%$, it is unlikely that our studied $D$. majalis populations suffered from limited services of the pollinator insects. Moreover, we found no significant positive correlation between the numbers of flowers and fruits as has been described by Vojtko et al. (2015) for D. majalis. The reason might be the fact that several flowering plants or their seeds disappeared in the nature before the fruit-assessment took place - a phenomenon which can likely be explained by plant poaching.

Note that within the superior seed-fertility cluster I, differing from cluster II by enhanced continental climate conditions, four out of six localities represented stands of the southern highlands and one additionally elevated site (Schlegel) was localized in closed neighborhood to them. Compared to the northern lowlands, higher amounts of incoming solar radiation and both larger daily and annual temperature differences between night and day as well as between summer and winter, respectively, have been recently recorded for the southern highlands (Flemming 2005). It has been furthermore assumed that the landscape of the northern lowlands, characterized by numerous lakes and ponds, is able to balance out more effectively ambient temperature differences (Flemming 2005). We did not investigate local site conditions using physical instruments. Yet, the instead applied Ellenberg's indicator values have been previously shown to deliver reliable ratings of the environmental conditions under which plant communities grow up (e.g., Seidling and Fischer 2008; Guarino et al. 2012). Our finding of viability selection among the tested embryos in association with differing thermal continentalities (see below) definitely underlines that climatic changes over space and time affected the study plots. Significant temperature effects on both the male and female organs of flowers have been already reported for dozens of plant species before pollination took place and during the post-pollination stage, but the underlying mechanisms of gene expression are currently only fragmentaryly understood as has been reviewed by Zinn et al. (2010) and Hedhly (2011).

\section{Genetic selection in response to continental climate stress}

We were able to detect a genetic selection due to the current climate stress, such that the environmentally controlled bipartite fertility pattern of seed samples exactly corresponded to the opposite frequency distribution of two prominent genotypes at locus ms 14 when comparing mother plants. Physiological differentiations among growing individuals are known to result from many kinds of abiotic stresses, revealing the existence of both adapted and unfit offspring, which are able to resist or perish, respectively (several case studies have been compiled by Schubert and Müller-Starck 2006). Apart from the observed clinal-fashioned genotype distribution seen along the identified climate gradient, gene-expression profiles could be useful to demonstrate that marker locus ms14 itself, or a closely linked not yet detected gene, may provide different protein variants responsible for fertility/sterility. Unfortunately, we cannot predict any possible gene function for locus ms 14 containing a CTT-repeat motif. The available 287 base-pairs showed no significant similarity when performing a nucleotide sequence alignment in publicly 
accessible databases (current releases of GenBank, GenomeNet, and EMBL nucleotide data libraries were repeatedly scanned via WWW using the procedures described by Claverie 1997). Differential fertilities among the offspring of plant hybrids are on the other hand frequently documented as a result of both altered chromosomal structures and numbers rather than being a product of disturbed gene expression (for detailed information see Futuyma 1986).

Reflecting the higher frequency of homozygous marker genotype EE within cluster I of beneficial seed fertility and the erratic meiotic processes recorded in megasporocytes, we argue that the germ-cells of mother plants bearing more fertile seeds are probably less affected by aneuploid chromosomal numbers and/or severe mutations of the chromosomal structure (e.g., deletions due to non-reciprocal translocations). The identified homozygote advantage perfectly fits the occurrence of aneuploid chromosomal numbers, since they are expected to have a strong negative impact on fertility in heterozygous constellation as issued by Futuyma (1986). Moreover, there is evidence that imbalance of gene dosage in deletion heterozygotes alters the phenotypic expression dramatically and can be injurious to the organism (Birchler et al. 2005). Aneuploidy or mutations of the chromosomal structure in linkage disequilibrium with the present genotype at microsatellite marker ms14, lying on a separate chromosome, thus appears as a plausible hypothesis to explain our current data. Besides a natural selection among adapted and non-adapted genotypes, random variation in small populations, population subdivision, genetic hitchhiking, and gene flow are the possible causes for linkage disequilibrium - a phenomenon characterized by allele frequencies which are not independently distributed at two or more loci. Such a linkage disequilibrium between two nonallelic genes on different chromosomes will only be maintained for the future if both gene products interact in metabolism by epistasis to make final protein products (for detailed information see Manly 1985). By contrast, epigenetic alterations of DNA methylation pattern in flowers have been recently shown to drive environmental adaptation in three closely related allopolyploid orchid species including $D$. majalis (Paun et al. 2010).

Keeping furthermore in mind that locus ms14 is present within the genome of $D$. fuchsii and absent within the genome of D. incarnata (Nordström and Hedrén 2007), previously undertaken crosses already suggested that $D$. fuchsii could control the seed fertility expressed in the natural hybrid $D$. majalis by an unknown maternal mechanism. Despite a high standard deviation, such crosses offered somewhat more viable seeds when $D$. fuchsii served as pollen recipient (mother plant) and $D$. incarnata was employed as pollen donor in comparison to a reverse order of operation (De hert et al. 2012).

D. majalis plants, owing disadvantageous genetic constellations to carry-out successful sexual reproduction under harsh continental climate conditions (e.g., DD or the remaining genotypes detected at locus ms 14 with the exception of EE), are nevertheless expected to be retained in the nature for longer times by vegetative propagation via auxiliary bulbs (Feldmann and Finke 2013). Asexual reproduction is, however, an evolutionary dead end and can only postpone extinction of a species to a later time (Luijten et al. 2000). A knowledge of species and genotypes conferring thermal stress tolerance is currently of upmost urgency, as has been pointed out by Hedhly (2011), in order to increase our understanding of how plants cope with fluctuating environmental conditions in the face of global climate change.

\section{What about inbreeding and gene flow?}

The few significant excesses of homozygosity detected in terms of HWE for markers ms 13 and ms 14 do not necessarily imply inbreeding because of the following reasons. I) Affected population nos. 5 and 9 were never concerned at all three studied marker loci. II) One locus, namely ms14, was recognized to sign a non-neutral genomic variation. III) The reduced embryo viability - a trait likely attributable to possible inbreeding - is also known to be an intrinsic genetic burden of allotetraploids hybrids under the condition of heterogeneic chromosomal recombination as pointed out at the start of the discussion. IV) Selfing, an extreme form of inbreeding, is unlikely due to the specific blossom morphology of D. majalis (Schoenichen 1940, experimentally shown by Vojtko et al. 2015) and pollinaria bending (discussed in Ostrowiecka et al. 2019). V) An elevated level of gene flow, counteracting possible inbreeding, will be expected with regard to the fact that the embryo is embedded into a surrounding scaffold of collapsed cork-like cells. This enables tiny seeds, reaching from 0.000002 to $0.000008 \mathrm{~g}$ in mass, to sail with the wind over larger distances than the pollinator insects usually move (Schoenichen 1940). In this context, it has been shown that bumblebees, being the main pollinators of Dactylorhiza species, rarely fly distances longer than $2 \mathrm{~km}$ between the nest and the flower heads (Walther-Hellwig and Frankl 2000). Analyzing 27 populations of D. majalis ssp. lapponica by 15 plastid and eight nuclear marker loci, Hedrén and co-workers (Hedrén et al. 2018) concluded that long-distance seed dispersal was the driving force to colonize the Baltic island of Gotland after the Ice Age, but this type of gene flow only has a minor impact on the contemporary genetic differentiation.

Considering the fact that diploid $D$. fuchsii exclusively occured side-by-side with allotetraploid D. majalis at stand no. 3 , a possible pollination between both species cannot be excluded and could be in part responsible for the striking low embryo viabilities found there and at stand no. 4 , which is situated a few hundred meters away. The offspring of such an interspecies cross is expected to display significantly 
lower rates of embryo viabilities in comparison to the offspring of pure species pollinations due to postzygotic barriers as has been demonstrated by De hert et al. (2012) with regard to three Dactylorhiza species including D. fuchsii and D. incarnata. Although D. majalis has a life-span of up to $30-$ 40 years (Harper 1977), it is unlikely that we sampled mother plants resulting from a recent putative pollination between D. fuchsii and D. incarnata. The latter is absent from Upper Lusatia since 1950 (Hardtke and Ihl 2000), whereas D. majalis has been highly abundant in the study area for over a century (Barber 1901). Consequently, it is moreover not plausible that our data are compromised by low fertility seeds representing hidden back-crosses between $D$. incarnata and D. majalis. Concerning other possible mating partners, no further Dactylorhiza species grew at any of the 12 study sites.

Due to the fact that the recorded genotypic data were in part affected by selection and furthermore indicate imbalances between genetic drift and gene flow, as confirmed by the moderate among-population genetic differentiation, we refrained from the calculation of indirect gene-flow estimates (Slatkin and Barton 1989) on the basis of individual $F_{S T}$ values for all three investigated markers. Such an estimation is generally not applicable under the aforementioned conditions (see Hamrick and Nason 2000). The $6 \%$ among-population differentiation identified for our study area is below the recently calculated mean for Orchidaceae (14.6\% according to Phillips et al. 2012), but is consistent with the data reported for some other orchid species, which are comparably distributed by pollination vectors and minute seeds (Hamrick and Godt 1996; Forrest et al. 2004; Chung et al. 2005). However, it should be mentioned that we only sampled mother plants at a limited regional scale in order to study their sexual reproduction. It is of note that inbreeding shapes the whole genome in contrast to selection (adaptation), which affects single genomic sites. Thus, at least 10 unlinked neutral markers (e.g., allozymes) are in sum necessary to exclude inbreeding in our study populations.

\section{Final conclusions for site-specific conservation management}

Counting the available numbers of flowering individuals per stand as well as checking over the numbers of blossoms and fruits per inflorescence as has been proposed by Heinrich (2013), did not deliver reliable information concerning the reproductive success of $D$. majalis. In the same line, no significant correlation existed between flowering, fruit-set, and seed-fertility. After manufacturing laborious embryo-viability stains, we surprisingly discovered that the outstanding large lowland population no. 3, which seemed to be attached to an optimal environment during the past, had the smallest seedfertility rate among all 12 investigated stands. The consequences of this result are not yet forseeable, but ongoing global warming is expected to provide additional stresses likely interfering with reproduction (for reviewing both local and world-wide effects of global warming see Flemming 2005 as well as Alcamo and Olesen 2012; resulting challenges in persuit of the welfare of orchids are outlined by Gale et al. 2018). Since the extent and effect of potential backcrossing of tetraploid D. majalis and diploid D. fuchsii at stand no. 3 and probably also no. 4 might in part be responsible for the very low embryo viabilities, this topic should thoroughly be investigated in the future. Further, populations no. 8 and no. 10 of the southern highlands, although characterized by superior embryo viabilities, could also be endangered due to their little population sizes (44 and 35 growing individuals, respectively). Fifty flowering individuals are at least necessary to produce a sizeable number of seedlings as has been estimated for the food deceptive orchid species Orchis purpurea by Jacquemyn et al. (2007). Focussing on the remarkable twolocus non-random linkage disequilibria exclusively identified in population no. 7 , the data could reflect the relatively small population size, or indicate genetic selection. Even allele frequency differences alone are sufficient to generate linkage disequilibrium (Smouse et al. 1983). Finally, taking into account the alarming facts described above, sexual reproduction of D. majalis should be regularly monitored within all 12 stands in the future, including embryo-viability stains and genetic inventories, to validate the long-term properties of our findings and to further refine monitoring strategies and conservation plans to prevent local extinction.

Acknowledgments Open Access funding provided by Projekt DEAL. We thank the local environmental protection authority, namely $\mathrm{Mr}$. Alexander Wünsche, for a permission to collect leaves, immature inflorescences, and fruits of $D$. majalis. We also thank the reviewers for their thoughtful comments that helped us to substantially improve the manuscript. This project was financially supported by two grants donated by the Ministry of Science and Art in Saxony.

\section{Compliance with ethical standards}

Conflict of interest The authors declare that they have no conflict of interest.

Open Access This article is licensed under a Creative Commons Attribution 4.0 International License, which permits use, sharing, adaptation, distribution and reproduction in any medium or format, as long as you give appropriate credit to the original author(s) and the source, provide a link to the Creative Commons licence, and indicate if changes were made. The images or other third party material in this article are included in the article's Creative Commons licence, unless indicated otherwise in a credit line to the material. If material is not included in the article's Creative Commons licence and your intended use is not permitted by statutory regulation or exceeds the permitted use, you will need to obtain permission directly from the copyright holder. To view a copy of this licence, visit http://creativecommons.org/licenses/by/4.0/. 


\section{References}

Alcamo J, Olesen JE (2012) Life in Europe under climate change. WileyBlackwell

Baack EJ, Rieseberg LH (2007) A genomic view of introgression and hybrid speciation. Curr Opin Genet Dev 17:513-518

Balao F, Tannhäuser M, Lorenzo MT, Hedrén M, Paun O (2016) Genetic differentiation and admixture between sibling allopolyploids in the Dactylorhiza majalis complex. Heredity 11:351-361

Barber E (1901) Flora der Oberlausitz preußischen und sächsischen Anteils einschließlich des nördlichen Böhmens. II Teil Die Gymnospermen und Monocotyledonen - Abh Naturforsch Ges Görlitz 23:1-169

Birchler JA, Riddle NC, Auger DL, Veitia RA (2005) Dosage balance in gene regulation: biological implications. Trends Genet 21:219-226

Bräutigam S, Otto H-W (2012) Rote Liste der Farn- und Samenpflanzen in der Oberlausitz: aktualisierte Fassung. Berichte der Naturforschenden Gesellschaft der Oberlausitz 20:99-116

Burke JM, Arnold ML (2001) Genetics and the fitness of hybrids. Annu Rev Genet 35:31-52

Chung MY, Nason JD, Chung MG (2005) Spatial genetic structure in populations of the terrestrial orchid Orchis cyclochila (Orchidaceae). Plant Syst Evol 254:209-219

Claessens J, Kleynen J (2011) The flower of the European orchid. Claessens and Kleynen, Geulle, The Netherlands

Claverie J-M (1997) Exon detection by similarity searches. In: Boultwood J (ed) Methods in mol biol. Vol 68: Gene isolation and mapping protocols. Humana Press Inc, Totowa, NJ, pp 283-313

Comai L (2005) The advantages and disadvantages of being polyploid. Nature Rev Genet 6:836-846

De Hert K, Jacquemyn H, van Glabeke S, Roldán-Ruiz I, Vandepitte K, Leus L, Honnay O (2012) Reproductive isolation and hybridization in sympatric populations of three Dactylorhiza species (Orchidaceae) with different ploidy levels. Ann Bot 109:709-720

Delforge P (2006) Orchids of Europe, Northern Africa and the Middle East. A. and C. Black, London

Devos N, Tyteca D, Raspe O, Wesseling RA, Jacquemart A-L (2003) Patterns of chloroplast diversity among western European Dactylorhiza species (Orchidaceae). Plant Syst Evol 243:85-97

Devos N, Raspe O, Oh S-H, Tyteca D, Jacquemart A-L (2006) The evolution of Dactylorhiza (Orchidaceae) allotetraploid complex: insights from nrDNA sequences and cpDNA PCR-RFLP data. Mol Phylogen Evol 38:767-778

Doyle JJ, Doyle JH (1990) Isolation of plant DNA from fresh tissue. Focus 12:13-15

Ellenberg H, Weber HE, Düll R, Wirth V, Werner W, Paulißen D (1992) Zeigerwerte von Pflanzen in Mitteleuropa. Scripta Geobotanica 18: $1-248$

Feldmann R, Finke L (2013) Austriebe auf Knollen und Rhizomen einige Beobachtungen an heimischen Orchideen an Thüringer Fundorten. Berichte aus den Arbeitskreisen Heimische Orchideen 30:62-70

Flemming G (2005) Das Klima der Oberlausitz. Berichte der Naturforschenden Gesellschaft der Oberlausitz 13:129-136

Forrest AD, Hollingsworth ML, Hollingsworth PM, Sydes C, Bateman RM (2004) Population genetic structure in European populations of Spiranthes romanzoffiana set in the context of other genetic studies on orchids. Heredity 92:218-227

Friendly M (1992) Graphical methods for categorical data. SAS User Group Intern Con Proc 17:190-200

Futuyma DJ (1986) Evolutionary biology. Sinauer Associates, Sunderland

Gale SW, Fischer GA, Cribb PJ, Fay MF (2018) Orchid conservation: bridging the gap between science and practice. Bot J Linn Soc 186: 425-434
Gregorius HR (1978) The concept of genetic diversity and its formal relationship to heterozygosity and genetic distance. Math Biosci 41:253-271

Gregorius HR (1987) The relationship between the concepts of genetic diversity and differentiation. Theor Appl Genet 74:397-401

Guarino R, Domina G, Pignatti S (2012) Ellenberg's indicator values for the flora of Italy - first update: Pteridophyta, Gymnospermae and Monocotyledoneae. F1 Medit 22:197-209

Hamrick JL, Godt MJW (1996) Effects of life history traits on genetic diversity in plant species. Philos Trans Soc B 351:1291-1298

Hamrick JL, Nason JD (2000) Gene flow in forest trees. In: Young A, Boshier D, Boyle T (eds) Forest conservation genetics. Principles and Practice. CSIRO Publishing and CABI Publishing, Collingwood and Wallingford, pp 81-90

Hardtke H-J, Ihl A (2000) Atlas der Farn- und Samenpflanzen Sachsens. In: Sächs. Landesanstalt für Umwelt und Geologie (Hrsg.). Materialien zu Naturschutz und Landespflege

Harper JL (1977) Population biology of plants. Acadmic Press, London

Hedhly A (2011) Sensitivity of flowering plant gametophytes to temperature fluctuations. Environ Exp Bot 74:9-16

Hedrén M (1996) Genetic differentiation, polyploidization and hybridization in northern European Dactylorhiza (Orchidaceae): evidence from allozyme markers. Plant Syst Evol 201:31-55

Hedrén M, Olofsson SN, Paun O (2018) Orchid colonization: multiple parallel dispersal events and mosaic genetic structure in Dactylorhiza majalis ssp. laponica on the Baltic island of Gotland. Ann Bot 122:1019-1032

Heinrich W (2013) Populationsökologie, Populationsdynamik heimischer Orchideen - Probleme, Aufgaben, Literaturhinweise 1. Fortsetzung Berichte aus den Arbeitskreisen Heimische Orchideen 30:71-104

Heslop-Harrison J (1953) Microsporogenesis in some triploid Dactylorhiza hybrids. Ann Bot 27:539-549

Hodges JL, Lehmann EL (1963) Estimates of location based on rank tests. Ann Math Statist 34:598-611

Hollander M, Wolfe DA, Chicken J (2015) Nonparametric statistical methods, Third edn. Wiley

Holm S (1979) A simple sequentially rejective multiple test procedure. Scand J Stat 6:65-70

Hothorn T, Hornik K, van de Miel MA, Zeileis A (2006) A lego system for conditional inference. Am Stat 60:257-263

Hunt PF, Summerhayes VS (1965) Dactylorhiza Nevski, the correct generic name of the Dactylorchids. Watsonia 6:128-133

Jacquemyn H, Vandepitte K, Brys R, Honnay O, Roldán-Ruiz I (2007) Fitness variation and genetic diversity in small, remnant populations of the food desceptive orchid Orchis purpurea. Biol Conserv 139: 203-210

Jäger EJ (2011) Rothmaler - Exkursionsflora von Deutschland. Gefäßpflanzen. Grundband. 20. Auflage. Spektrum Akademischer Verlag, Heidelberg

Karp A (1994) Origins, causes and uses of variation in plant tissue cultures. In: Vasil IK, Thorpe TA (eds) Plant cell and tissue culture. Kluwer Academic Publishers, Dordrecht, pp 139-151

Kendall MG (1955) Rank correlation methods. Charles Griffin and Company, London

Kondratyev KY, Grigoryev AA, Varotsos CA (2002) Environmental disasters anthropogenic and natural. Springer, London, Praxis Publishing Ltd., Unichester, UK

Kreienkamp F, Spekat A, Enke W (2011) Bereitstellung eines Ensembles regionaler Klimaprojektionen für Sachsen. Landesamt für Umwelt, Landwirtschaft und Geologie

Kruskal WH, Wallis WA (1952) Use of ranks in one-criterion variance analysis. J Am Stat Assoc 47:614-617

Liu Z, He C, Wu I (2016) The relationship between habitat loss and fragmentation during urbanization: an empirical evaluation from 16 world cities. PLoS One 11:e0154613 
Ludwig G, May R, Otto C (2007) Verantwortlichkeit Deutschlands für die weltweite Erhaltung der Farn- und Blütenpflanzen - vorläufige Liste. BfN-Skripten 220:1-102

Luijten SH, Dierick A, Gerard J, Oostermeijer B, Raijmann LEL, Den Nijs HCM (2000) Population size, genetic variation, and reproductive success in a rapidly declining, self-incompatible perennial (Arnica montana) in the Netherlands. Cons Biol 14:1776-1787

Mallet J (2005) Hybridization as an invasion of the genome. Trends Ecol Evol 20:229-237

Manly BFJ (1985) Tests of the theory of natural selection: an overview. J Royal Soc New Zeal 15:411-432

Mann HB, Whitney DR (1947) On a test of whether one of two random variables is stochastically larger than the other. Ann Math Stat 18: $50-60$

McDonald JH (2014) Handbook of biological statistics, 3rd edn. Sparky House Publishing, Baltimore

Meyer D, Zeileis A, Hornik K (2003) Visualizing independence using extended association plots. In: Hornik K, Leisch F, Zeileis A (eds) Proc of the $3^{\text {rd }}$ intern workshop on distributed statistical computing, ISSN 1609-39X

Meyer D, Zeileis A, Hornik K (2006) The Strucplot framework: visualizing multi-way contingency tables with ved. J Stat Softw 17:1-48

Meyer D, Zeileis A, Hornik K (2017) vcd: visualizing categorical data. $R$ package version 1.4-4

Nei M (1972) Genetic distance between populations. Chapman and Hall, London

Nei M (1973) Analysis of gene diversity in subdivided populations. Proc Natl Acad Sci U S A 70:3321-3323

Neiland MRM, Wilcock CC (1998) Fruit-set, nectar reward, and rarity in the Orchidacea. Am J Bot 85:1657-1671

Nordström S, Hedrén M (2007) Development of polymorphic nuclear microsatellite markers for polyploid and diploid members of the orchid genus Dactylorhiza. Mol Ecol Notes 7:644-647

Ostrowiecka B, Tałałaj I, Brzosko E, Jermakowicz E, Mirski P, KostroAmbroziak A, Mielczarek Ł, Lasoń A, Kupryjanowicz J, Kotowicz J, Wróblewska A (2019) Pollinators and visitors of the generalized food-deceptive orchid Dactylorhiza majalis in north-eastern Poland. Biologia 74:1247-1257

Paun O, Bateman RM, Fay MF, Hedrén M, Civeyrel L, Chase MW (2010) Stable epigenetic effects impact adaptation in allopolyploid orchids (Dactylorhiza: Orchidaceae). Mol Biol Evol 27:2465-2473

Paun O, Bateman RM, Fay FM, Luna JA, Moat J, Hedrén M, Chase MW (2011) Altered gene expression and ecological divergence in sibling allopolyploids of Dactylorhiza (Orchidaceae). BMC Evol Biol 11: 113

Phillips RD, Dixon KW, Peakall R (2012) Low population genetic differentiation in the Orchidaceae: implications for the diversification of the family. Mol Ecol 21:5208-5220

Riecken U, Finck P, Raths U, Schröder E, Ssymank A (2006) Rote Liste der gefährdeten Biotoptypen Deutschlands: zweite fortgeschriebene Fassung. Naturschutz und Biologische Vielfalt 34:1-318

R Core Team (2017) R: A language and environment for statistical computing. R Foundation for Statistical Computing, Vienna, Austria

Rode P, Schadwinkel H-J (2014) Dactylorhiza majalis (Rchb.) P. F. Hunt and Summerh. Breitblättriges Knabenkraut, Mai-Kuckucksblume. In: Heinrich W, Voelckel H, Dietrich H, Feldmann R, Geithner A, Kögler V, Rode P, Westhus W (eds) Thüringens Orchideen. Uhlstädt-Kirchhasel, Arbeitskreis Heimischer Orchideen Thüringen e.V, pp 395-405

Sass JE (1958) Botanical Microtechnique. Iowa State University Press, Ames

Schoenichen W (1940) Biologie der geschützten Arten Deutschlands. Eine Einführung in die lebenskundliche Betrachtung heimischer Gewächse. Verlag Gustav Fischer, Jena

Schubert R, Müller-Starck G (2006) Bioindication via monitoring genetic variation in tree populations: tools applicable under stressful environments. In: Filho WL, Greif D, Delakowitz B (eds) sustainable chemistry and biotechnology - a contribution to Rivers management vol 21, environmental education, communication and sustainability. W. L. Filhao (ed) Peter Lang Europäischer Verlag der Wissenschaften, Frankfurt am Main, Berlin, Bern, pp 151-164

Seidling W, Fischer R (2008) Deviances from expected Ellenberg indicator values for nitrogen are related to $\mathrm{N}$ throughfall deposition in forests. Ecol Indic 8:639-646

Sham P, Curtis D (1995) Monte Carlo test for association between disease and alleles at highly polymorphic loci. Ann Hum Genet 59:97-105

Slatkin M, Barton NH (1989) A comparison of three indirect methods for estimating average levels of gene flow. Evol 43:1349-1368

Smouse PE, Neal JV, Liu W (1983) Multiple-locus departures from panmictic equilibrium within and between village gene pools of Amerindian tribes at different stages of agglomeration. Genetics 104:133-153

Soltis PS, Soltis DE (2009) The role of hybridization in plant speciation. Annu Rev Plant Biol 60:561-588

Sonkoly J, Vojtkó AE, Tökölyi J, Török P, Sramkó G, llyés Z, Molnár VA (2015) Higher seed number compensates for lower fruit set in deceptive orchids. J Ecol 104:343-351

Soó R (1960) Synopsis Generis Dactylorhiza (Dactylorchis). Ann Univ Sci Budap de Rolando Eötvös nom Sect Biol 3:335

Van Waes JM, Debergh PC (1986) Adaptation of the tetrazolium method for testing the seed viability, and scanning electron microscopy study of some western European orchids. Physiol Plant 66:435-442

Vojtko AE, Sonkoly J, Lukács BA, Molnár VA (2015) Factors affecting reproductive success in three entomophilous orchid species in Hungary. Acta Biol Hung 66:231-241

Walther-Hellwig K, Frankl R (2000) Foraging habitats and foraging distances of bumblebees, Bombus spp. (Hym., Apidae), in an agricultural landscape. J Appl Entomol 124:299-306

Ward JH (1963) Hierarchical grouping to optimize an objective function. J Am Stat Assoc 58:236-244

Warnes G, with contributions from Gorjanc G, Leisch F, Man M (2013) genetics: Population Genetics. $R$ package version 1.3.8.1

Weischet W, Endlicher W (2000) Regionale Klimatologie. Teil 2 Die Alte Welt Europa, Afrika, Asien. Teubner Studienbücher der Geographie, Stuttgart, Leipzig

Wotavová K, Balounová Z, Kindlmann P (2004) Factors affecting persistence of terrestrial orchids in wet meadows and implications for their conservation in a changing agricultural landscape. Biol Conserv 118:271-279

Wright S (1978) Evolution and the genetics of populations. Vol. 4 Variability within and among natural populations. University of Chicago Press, Chicago

Wróblewska A, Szcepaniak L, Bajguz A, Jedrzejczyk I, Tałałaj L, Ostrowiecka B, Brzosko E, Jermakowicz E, Mirski P (2019) Deceptive strategy in Dactylorhiza orchids: multidirectional evolution of floral chemistry. Ann Bot 123:1005-1016

Yeh FC (2000) Population genetics. In: Young A, Boshier D, Boyle T (eds) Forest conservation genetics. Principles and Practice. CSIRO Publishing and CABI Publishing, Collingwood, and Wallingford, pp 21-37

Zeileis A, Meyer D, Hornik K (2007) Residual-based shadings for visualizing (conditional) independence. J Comput Graph Stat 16:507525

Zinn KE, Tunc-Ozdemir M, Harper JF (2010) Temperature stress and plant sexual reproduction: uncovering the weakest links. J Exp Bot 61:1959-1968

Publisher's note Springer Nature remains neutral with regard to jurisdictional claims in published maps and institutional affiliations. 